\title{
Neoplastic meningitis in malignant melanoma: diagnosis with monoclonal antibodies
}

\author{
R P MOSELEY,* A G DAVIES, * S P BOURNE, ${ }^{*}$ C POPHAM,$\dagger$ S CARREL $\ddagger$ \\ P MONRO,§ H B COAKHAM*
}

From the Brain Tumour Research Laboratory, Department of Neurosurgery, ${ }^{*}$ and Skin Cancer Research Fund, Department of Plastic Surgery, $\dagger$ Frenchay Hospital, Bristol, UK, Ludwig Institute for Cancer Research, Lausanne Branch, University of Lausanne, $\ddagger$ Switzerland, and the Department of Neurology, Atkinson Morley's Hospital,§ London, UK

SUMMARY Six patients with neoplastic melanomatous meningitis were studied. The diagnosis of this complication of malignant disease rests on the demonstration of malignant cells within the CSF. The addition of monoclonal antibody immunocytology to conventional techniques significantly improved the diagnostic sensitivity of CSF cytology, allowing for earlier and therefore more effective palliative treatment.

Neoplastic meningitis is characterised by diffuse or multifocal infiltration of the leptomeninges by tumour cells, with or without associated intraparenchymal lesions.' Apart from primary neuroectodermal tumours and haemopoietic malignancies, the other tumours that commonly lead to meningeal spread include primary lesions of lung, ${ }^{2}$ breast, ${ }^{3}$ gastro-intestinal tract ${ }^{4}$ and malignant melanoma. ${ }^{5}$ The diagnosis of neoplastic meningitis is achieved by the demonstration of malignant cells in the cerebrospinal fluid (CSF). Conventional CSF cytological methods are frequently unsatisfactory, giving wide variation in diagnostic sensitivity, with reported rates of detection of malignant cells as low as $20 \%$ in some series. ${ }^{6}$ When malignant cells are demonstrated by such techniques, it is frequently impossible to determine the neoplastic cell type, which can be of vital importance to clinical management when the nature of the primary tumour is unknown. The superior diagnostic accuracy of monoclonal antibody immunocytology of CSF has previously been reported ${ }^{7}$ and continues to be used on a regular basis in our laboratory in conjunction with routine cytological methods. We report six cases of neoplastic meningitis complicating malignant melanoma, in which the diagnosis was made by immunocytological examination of CSF with a panel of selected monoclonal antibodies. By conventional

Address for reprint requests: Mr R P Moseley, Brain Tumour Research Laboratory, Department of Neurosurgery, Frenchay Hospital, Frenchay, Bristol, BS16 1LE, UK.

Received 6 May 1988 and in revised form 7 November 1988. Accepted 24 January 1989 cytological techniques the diagnosis of meningeal neoplasia was confirmed in only three of these patients, and in only one of these was malignant melanoma confirmed.

\section{Methods}

\section{Patients}

Five patients with suspected neoplastic meningitis were investigated in the Department of Neurosurgery, Frenchay Hospital, Bristol; and one patient was investigated in the Department of Neurology, Atkinson Morley's Hospital, London. The clinical details of all patients studied are shown in Table 1. Two patients (cases 4 and 6), underwent craniotomy for removal of isolated tumour metastases, and during the procedure had insertion of an Ommaya reservoir ventriculostomy to enable the administration of radioimmunotherapy at a later date. In two patients (cases 1 and 2) the primary neoplasm was unknown.

\section{CSF samples}

Samples of CSF were obtained by lumbar puncture, or else by needle aspiration from an Ommaya reservoir ventriculostomy. Routine cytological and immunocytological examination was performed immediately on the fresh CSF specimens.

\section{Monoclonal antibodies}

Table 2 lists the antibodies used in this study together with details of their specificities and origins. Most of these have been extensively characterised by indirect immunofluorescence on a wide range of normal and neoplastic tissues. The antibodies described here consist of the standard diagnostic panel used in our laboratory. This included an antibody recognising melanoma (9.2.27). Two additional anti-melanoma reagents (NKI/C3, Mel-14) were used in those cases 
Table 1 Clinical and laboratory findings in melanomatous meningitis

\begin{tabular}{|c|c|c|c|c|c|c|c|}
\hline Case & $\begin{array}{l}\text { Age } \\
(y r)\end{array}$ & Clinical features & $\begin{array}{l}\text { Site of } \\
\text { primary } \\
\text { melanoma }\end{array}$ & $\begin{array}{l}\text { Routine CSF } \\
\text { cytology }\end{array}$ & $\begin{array}{l}\text { CSF immuno- } \\
\text { cytology }\end{array}$ & $\begin{array}{l}\text { Survival } \\
\text { after } \\
\text { diagnosis }\end{array}$ & Necropsy \\
\hline 1 & 35 & $\begin{array}{l}\text { Raised intracranial } \\
\text { pressure. Dysphasia. } \\
\text { Fluctuating } \\
\text { hemiparesis. Previous } \\
\text { excision of giant } \\
\text { cutaneous melanotic } \\
\text { neavus in childhood. } \\
\text { CT scan: Minimal } \\
\text { hydrocephalus }\end{array}$ & Leptomeninges & $\begin{array}{l}\text { Lymphocytic pleocytosis. } \\
\text { Malignant cells seen. } \\
\text { Characterised as neuro- } \\
\text { ectodermal. }\end{array}$ & $\begin{array}{l}\text { Positive } \\
\text { identification of } \\
\text { malignant } \\
\text { melanoma cells. }\end{array}$ & 14 weeks & 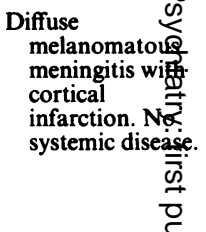 \\
\hline 2 & 35 & $\begin{array}{l}\text { Raised intracranial } \\
\text { pressure. Seizures and } \\
\text { blindness. CT scan: } \\
\text { Minimal } \\
\text { hydrocephalus. }\end{array}$ & Leptomeninges & $\begin{array}{l}\text { Initial investigation } \\
\text { revealed lymphocytic } \\
\text { infiltrate only. } \\
\text { Subsequent CSF } \\
\text { samples revealed } \\
\text { malignant cells of } \\
\text { undetermined origin. }\end{array}$ & $\begin{array}{l}\text { Positive } \\
\text { identification of } \\
\text { malignant } \\
\text { melanoma cells. }\end{array}$ & 3 weeks & 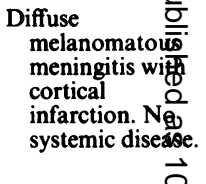 \\
\hline 3 & 62 & $\begin{array}{l}\text { Raised intracranial } \\
\text { pressure. Cutaneous } \\
\text { melanoma excised from } \\
\text { trunk } 2 \text { years } \\
\text { previously. CT scan: } \\
\text { normal. }\end{array}$ & Cutaneous & $\begin{array}{l}\text { Lymphocytic pleocytosis } \\
\text { and malignant cells } \\
\text { with features } \\
\text { characteristic of } \\
\text { malignant melanoma. }\end{array}$ & $\begin{array}{l}\text { Positive } \\
\text { identification of } \\
\text { malignant } \\
\text { melanoma cells. }\end{array}$ & 1 week & $\begin{array}{l}\text { Diffuse } \\
\text { melanomatous } \\
\text { meningitis anga } \\
\text { small isolated } \\
\text { intraparenchyina } \\
\text { temporal lobe } \\
\text { deposit. } \\
\text { Widespread } \\
\text { systemic } \\
\text { metastatic diseg: } \\
\text { (fig 2). }\end{array}$ \\
\hline 4 & 30 & $\begin{array}{l}\text { Raised intracranial } \\
\text { pressure and seizures. } \\
\text { Cutaneous melanoma } \\
\text { excised from right } \\
\text { lower limb } 4 \text { years } \\
\text { previously. CT scan: } \\
\text { Small tumour nodule in } \\
\text { right Sylvian fissure. } \\
\text { Craniotomy revealed } \\
\text { widespread pial } \\
\text { involvement by } \\
\text { tumour. } \\
\text { Radioimmunotherapy. }\end{array}$ & Cutaneous & $\begin{array}{l}\text { Scattered lymphocytes. } \\
\text { No malignant cells } \\
\text { seen. }\end{array}$ & $\begin{array}{l}\text { Positive } \\
\text { identification of } \\
\text { malignant } \\
\text { melanoma cells. }\end{array}$ & $\begin{array}{l}12 \text { months: } \\
\text { Remission } \\
\text { radioimmu- } \\
\text { notherapy. }\end{array}$ & 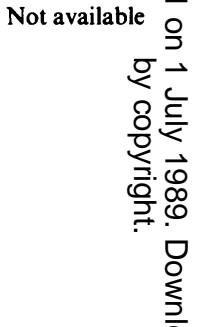 \\
\hline 5 & 64 & $\begin{array}{l}\text { Raised intracranial } \\
\text { pressure. Sciatica. } \\
\text { Cutaneous melanoma } \\
\text { excised from chest wall } \\
6 \text { months previously. } \\
\text { CT scan: isolated right } \\
\text { frontal paraventricular } \\
\text { tumour metastasis. } \\
\text { Craniotomy for } \\
\text { removal of tumour } \\
\text { metastasis. }\end{array}$ & Cutaneous & $\begin{array}{l}\text { Scattered lymphocytes. } \\
\text { No malignant cells } \\
\text { seen. }\end{array}$ & $\begin{array}{l}\text { Positive } \\
\text { identification of } \\
\text { malignant } \\
\text { melanoma cells } \\
\text { (fig 1). }\end{array}$ & 3 weeks & 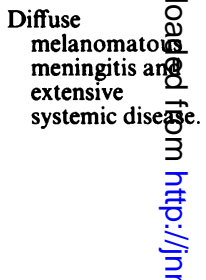 \\
\hline 6 & 53 & $\begin{array}{l}\text { Right occipital } \\
\text { craniotomy for excision } \\
\text { of isolated melanoma } \\
\text { deposit. } 1 \text { year later, } \\
\text { craniotomy for excision } \\
\text { of isolated frontal } \\
\text { melanoma deposit. } \\
\text { Both presented with } \\
\text { spontaneous } \\
\text { intracranial } \\
\text { haemorrhage. } \\
\text { Radioimmunotherapy. }\end{array}$ & Unknown & $\begin{array}{l}\text { Scattered lymphocytes. } \\
\text { No malignant cells } \\
\text { seen. }\end{array}$ & $\begin{array}{l}\text { Positive } \\
\text { identification of } \\
\text { malignant } \\
\text { melanoma cells. }\end{array}$ & $\begin{array}{l}\text { Alive and well } \\
\text { with no } \\
\text { symptoms } 1 \\
\text { year } \\
\text { following } \\
\text { radioimmu- } \\
\text { notherapy. }\end{array}$ & 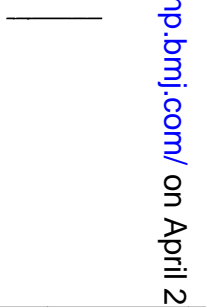 \\
\hline
\end{tabular}

where melanoma was suspected. In cases 1 and 2 , antibody $\mathrm{NKI} / \mathrm{C} 3$ was used later to confirm diagnosis and permit comparison with the other cases.
Immunocytology technique

Cell preparations were made on gelatin coated glass slides. Previously this involved a cytocentrifugation technique 
Table 2 Monoclonal antibody panel for melanoma diagnosis

\begin{tabular}{|c|c|c|c|c|}
\hline $\begin{array}{l}\text { Monoclonal } \\
\text { Antibody }\end{array}$ & Immunogen & Antigen & Tissue Distribution & Reference \\
\hline 9.2 .27 & Human melanoma line & $\begin{array}{l}\text { Membrane glyco-protein MW. } \\
240 \mathrm{~K}\end{array}$ & $\begin{array}{l}\text { Melanoma. Blood vessels. Some } \\
\text { CNS tumours }\end{array}$ & 8 \\
\hline NKI/C3 & $\begin{array}{l}\text { Plasma membrane from human } \\
\text { melanoma cell line }\end{array}$ & $\begin{array}{l}\text { Cytoplasmic glycoprotein } \mathrm{MW} \text {. } \\
25-110 \mathrm{~K}\end{array}$ & $\begin{array}{l}\text { Benign and malignant } \\
\text { melanocytic tumours. Some } \\
\text { carcinoma }\end{array}$ & 9 \\
\hline Mel-14 & Malignant melanoma & $\begin{array}{l}\text { Membrane glyco-protein MW. } \\
240 \mathrm{~K}\end{array}$ & $\begin{array}{l}\text { Melanoma, blood vessels. Some } \\
\text { CNS tumours }\end{array}$ & 10 \\
\hline Anti-S100* & $\mathrm{S}-100$ protein & S-100 protein & $\begin{array}{l}\text { All normal and neoplastic, neuro- } \\
\text { ectodermal tissue including } \\
\text { melanoma }\end{array}$ & 11 \\
\hline UJ13A & 16 week human foetal brain & Membrane glycoprotein & $\begin{array}{l}\text { All normal and neoplastic, neuro- } \\
\text { ectodermal tissue excluding } \\
\text { melanoma }\end{array}$ & 12 \\
\hline $\begin{array}{l}\text { LE61 } \\
\text { UJ181·4 } \\
2 \mathrm{D} 1\end{array}$ & $\begin{array}{l}\text { Marsupial kidney cell line } \\
16 \text { week human foetal brain } \\
\text { Human mono-nuclear cells }\end{array}$ & $\begin{array}{l}\text { Cytokeratin MW. } 45 \mathrm{~K} \\
\text { Membrane onco-foetal antigen } \\
\text { HLe-1 Membrane antigen. MW. } \\
\text { 220K }\end{array}$ & $\begin{array}{l}\text { Simple epithelia, carcinomas } \\
\text { Neuroblastic tumours } \\
\text { Pan-leucocyte lymphomas }\end{array}$ & $\begin{array}{l}13 \\
14 \\
15\end{array}$ \\
\hline
\end{tabular}

which has been described previously. ${ }^{16}$ More recently we have achieved more efficient cell harvesting by allowing $25 \mu \mathrm{l}$ of cell concentrates of CSF to dry directly onto gelatin coated glass slides. The slides were then immersed into cold acetone at $-30^{\circ} \mathrm{C}$ for 30 seconds to achieve light fixation. It appears that the antigens recognised by our antibody panel are not significantly affected by this treatment, which promotes adhesion of cells to the slide and thus prevents large losses of cells during washes. Following preparation, the slides were then immersed in phosphate buffered saline (PBS) for 5 minutes. Excess PBS was removed and $50 \mu \mathrm{l}$ of the appropriately diluted monoclonal antibody applied and incubated for 30 minutes at room temperature. PBS was used as a negative control. Slides were then washed twice in PBS and incubated for a further $\mathbf{3 0}$ minutes at room temperature with $50 \mu \mathrm{l}$ of appropriately diluted fluorescein conjugated rabbit anti-mouse immunoglobulin. Unbound fluorescein conjugate was removed by washing twice in PBS and the slides finally mounted in $90 \%$ glycerol/10\% PBS. A Zeiss Standard 14 microscope fitted for epifluorescence was used to examine the slide preparations at $400 \times$ magnification. Separate slides were used for each antibody and also for conventional cytology using May-Grunwald/ Giemsa and Masson/Fontana stains. The antibodies NKI/C3 and Anti$\mathrm{S} 100$ work on fixed cell preparations and therefore the appropriate slides were immersed in $10 \%$ formalin solution for 5 minutes and then rehydrated in PBS, prior to application of antibody.

Table 3 Monoclonal antibody profile of CSF cells

\begin{tabular}{lllllllll}
\hline & & NKII & Mel- & & & & \\
& $9 \cdot 2 \cdot 27$ & $C 3$ & 14 & S100 & UJ13A & LE61 & UJ181.4 & $2 D 1^{*}$ \\
\hline 1 & + & + & NA & + & - & - & - & + \\
2 & + & + & NA & + & - & - & - & + \\
3 & + & + & NA & + & - & - & - & + \\
4 & + & + & + & - & - & - & - & + \\
5 & + & + & - & NA & - & - & - & + \\
6 & + & + & + & NA & - & - & - & + \\
\hline
\end{tabular}

*Normal lymphocyte infiltrate positive. NA, not available.

\section{Results}

A diagnostic panel of up to eight antibodies was used to examine the CSF from six patients (table 2). Table 3 shows details of the immunocytological staining

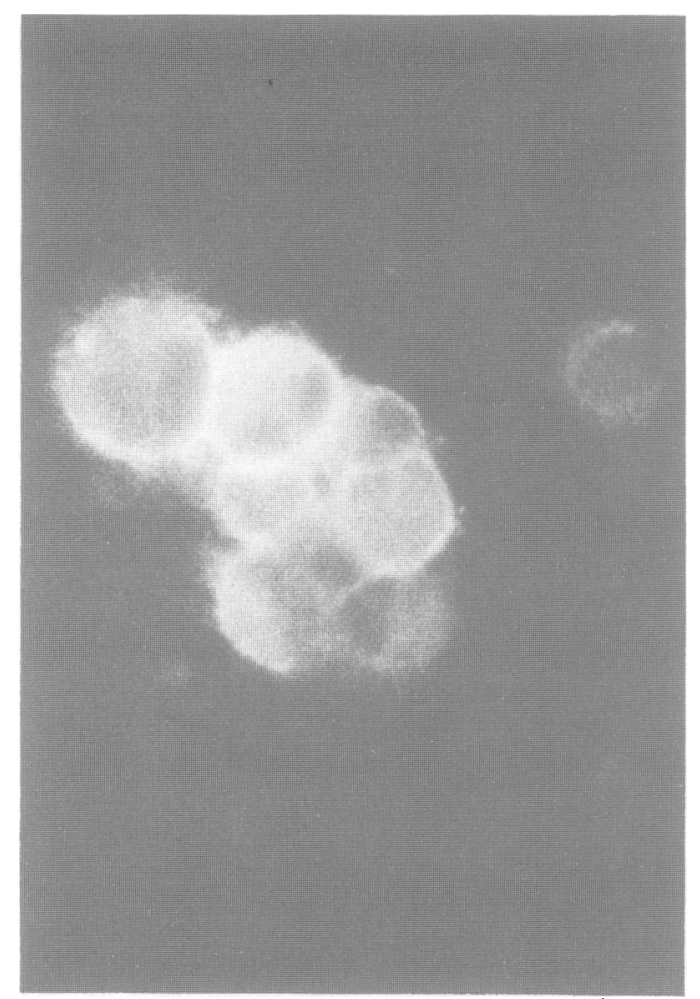

Fig 1 A cytospin CSF preparation from case 5 showing bright immunofluorescence with the antibody 9.2.27, which recognises a melanoma associated antigen. $(\times 500)$. 


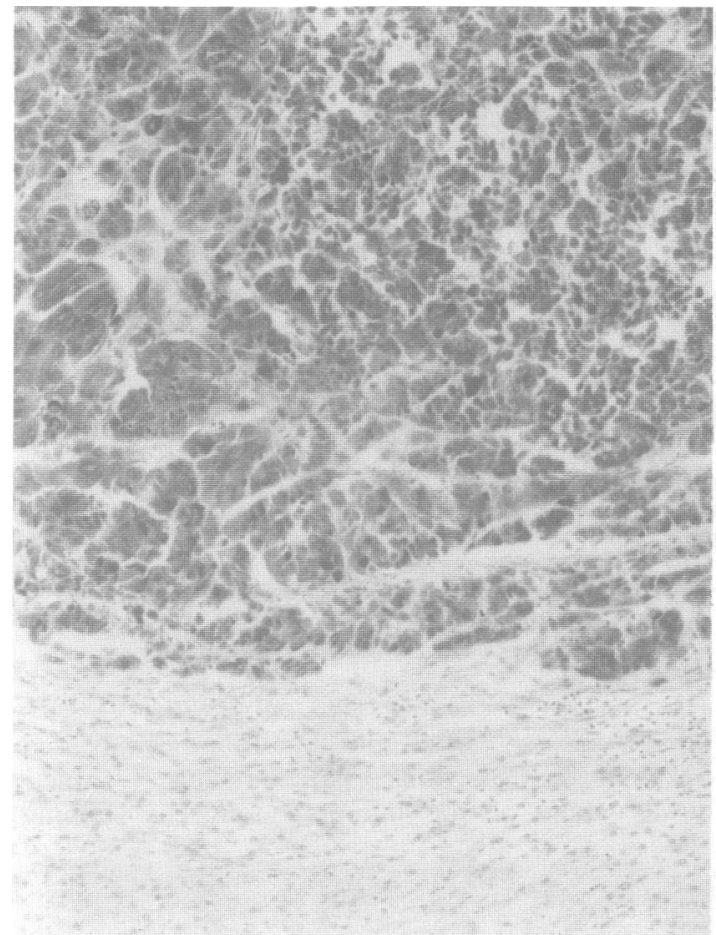

Fig 2 Histological section of a malignant melanomatous metastatic deposit in liver obtained at necropsy from case 3. Dark immunoperoxidase staining of tumour, with the antibody NKI/C3 contrasts markedly with adjacent nonstaining liver tissue. $(\times 100)$.

profiles against the panel. The cells from all six cases reacted positively with antibodies 9.2 .27 and NKI/C3 (fig 1, table 3). The antibody NKI/C3 has proven to be a valuable marker for melanoma in histological sections, more accurate than antibody for $\mathrm{S}-100$ protein $^{17}$ (fig 2). The antibody Mel-14 reacted with cells from two of three cases. This may arise either from true heterogeneity in tumour antigen expression or else from natural variation in cell numbers harvested by the cytocentrifuge technique, resulting in one preparation which lacked tumour cells. It is noteworthy, that all melanoma cells examined in this series expressed the intermediate filament protein Vimentin (fig 3), which is typically seen in mesenchymal tumours, lymphomas and melanomas. ${ }^{18}$ Vimentin expression is not seen in carcinomas, but some primary central nervous system tumours express this protein. ${ }^{19}$ This marker therefore appears to have a less valuable diagnostic role, and the antibody has therefore not been routinely used in our diagnostic panel. The consistently negative reaction of all cells to the antibodies UJ13A, LE61, and UJ181.4, further consolidates the diagnosis of malignant melanoma.

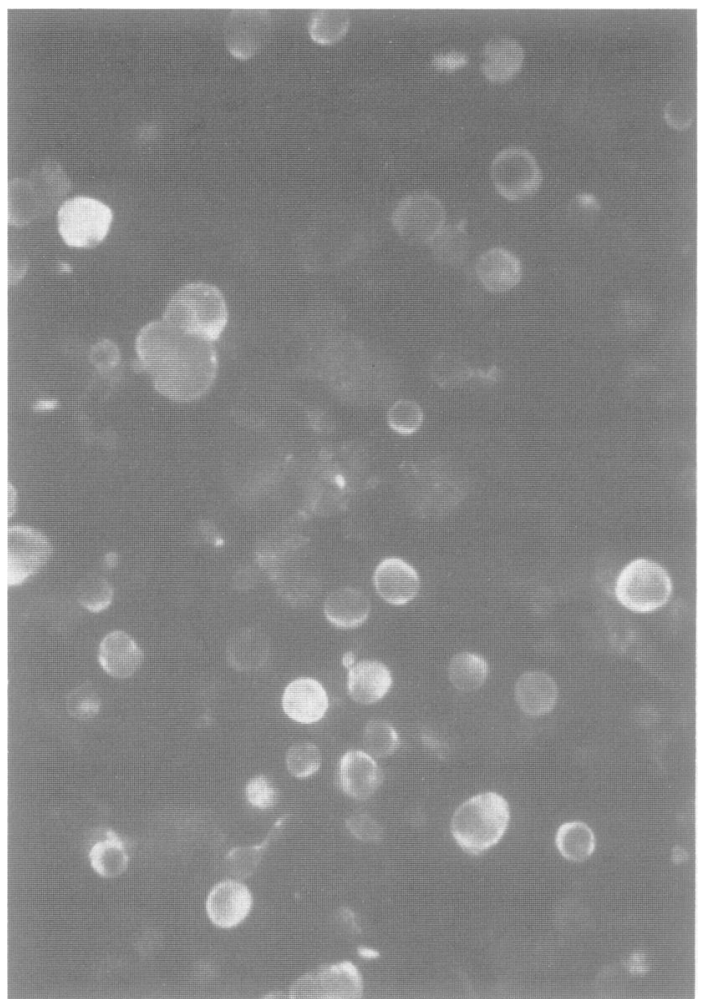

Fig 3 An air dried preparation of melanoma cells from case 5 showing positive immunofluorescence for Vimentin. $(\times 200)$.

As discussed later, these observations emphasise the importance of testing cell types against a whole panel of antibodies rather than against a single antibody. In particular, UJ13A is consistently reactive with all cells from neuroectodermal tumours with the exception of melanoma. The reactivities of the antibodies described in table 2 have been assessed on 252 cases of CNS tumour biopsies ${ }^{25}$ and on CSF cytological specimens. ${ }^{76}$ Non-neoplastic meningitis preparations are entirely leucocytic (antibody $2 \mathrm{D} 1+$ ve) or contain occasional normal neuroectodermal cells (UJ13A + ve).

In this series of patients with neoplastic melanomatous meningitis, the advantages of the immunological technique over more conventional methods of CSF cytology can clearly be seen. With immunocytology malignant cells were demonstrated in the CSF of all six patients. The malignant cell type was also revealed, thus enabling an assessment of the likely site and nature of the primary tumour. These findings are in marked contrast to results obtained by routine CSF cytological techniques which resulted in detection of tumour cells in the CSF of three patients. In 
only one of these it was possible to characterise the malignant cell type as that of melanoma.

\section{Discussion}

Malignant melanoma of the central nervous system (CNS) may be either primary or secondary, although the latter category is by far the most common. In these two categories of disease, tumours may be intraparenchymal, leptomeningeal or commonly in a combination of both sites. The reported incidence of CNS metastases in patients with malignant melanoma varies according to whether data has been accumulated from clinical or autopsy studies. Whilst an incidence of over $90 \%$ has been reported ${ }^{20}$; the largest necropsy study to date, from the Roswell Park Memorial Institute, ${ }^{21}$ reports the incidence of CNS metastatic disease as $54.6 \%$. In this large series of 216 patients with malignant melanoma, leptomeningeal infiltration was seen in $\mathbf{2 4 . 1 \%}$ of cases, thus occurring in $44 \%$ of patients with CNS metastatic disease. Interestingly, in a separate clinico-pathological study of malignant melanoma, ${ }^{5}$ leptomeningeal metastases were seen at necropsy in $70 \%$ of all patients clinically diagnosed as having CNS disease. This disparity would suggest that although significant intraparenchymal disease may remain clinically silent, the development of leptomeningeal tumour is rapidly accompanied by distressing symptoms. As it may now be possible to offer palliative treatment for neoplastic meningitis in the form of antibody-guided irradiation $^{23-24}$ it would seem justifiable to actively exclude leptomeningeal dissemination of tumour in patients with advanced malignant disease, who develop neurological symptoms or signs. We therefore suggest that in such patients, accurate staging of CNS involvement be undertaken initially by CT to assess intraparenchymal disease. In the absence of intracranial mass lesions, this should be followed by lumbar puncture to obtain CSF for diagnostic cytology and also by myelography if appropriate.

Previous reports have demonstrated the important diagnostic contribution of monoclonal antibody technology to CSF cytology, increasing the rate of positive diagnosis to $95 \% .^{16}$ With routine cytological staining techniques, false negative results may arise when small numbers of neoplastic cells are concealed by a reactive leucocytosis. False positive results may occur because reactive histiocytes tend to imbibe fluid and mimic the signet ring cells of adenocarcinoma. ${ }^{6}$ These problems are overcome by the use of immunocytological methods. The recognition of even a single malignant cell in a large population of reactive lymphocytes is possible when it is made to fluoresce brightly on a dark background (fig 4). Most importantly, malignant cells, once detected, can be accurately characterised by means of their antigenic profile, whereas such characterisation is generally not possible using conventional

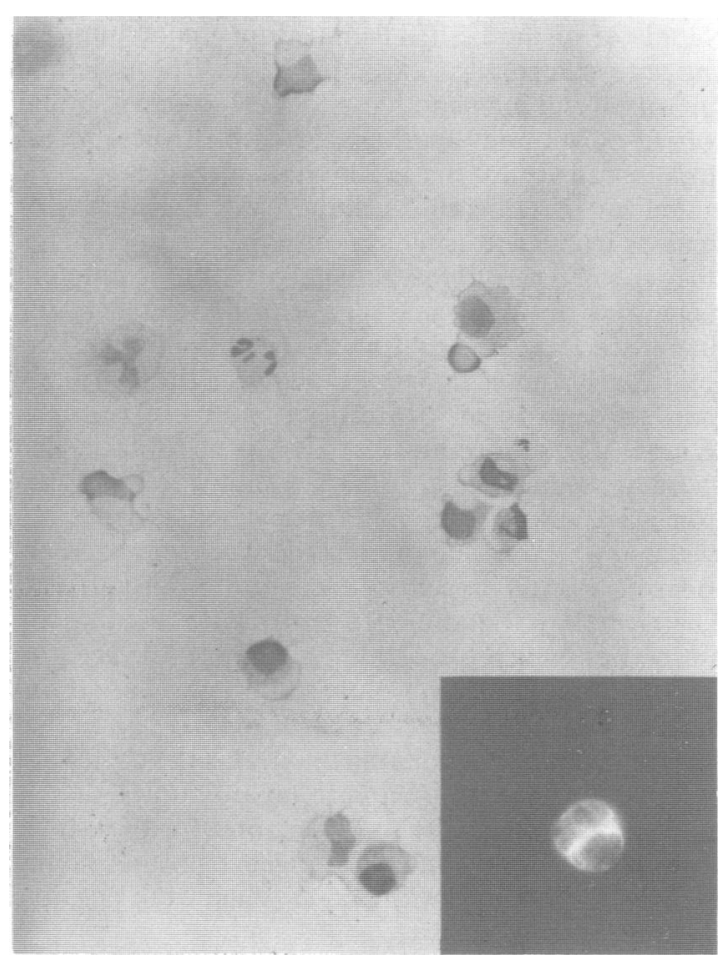

Fig 4 Cytospin preparation of CSF from a case of suspected neoplastic meningitis showing non-specific degenerate cells. ( $H \& E \times 400)$. (Inset) $A$ single cell in this preparation showing immunofluorescence with an antibody recognising cytokeratin expressed by epithelial cells. This led to further investigations which revealed a gastric carcinoma. $(\times 200)$.

techniques. In our experience there have been no false positive results with the immunocytological technique, which when used in conjunction with traditional cytological methods offers the most precise CSF examination available. ${ }^{726}$ Other techniques for identifying melanoma cells exist, such as DOPA oxidase histocytochemistry and electron microscopy. However, to our knowledge, these have not been applied to CSF cytological preparations. ${ }^{726}$

Generally, monoclonal antibodies do not have absolute cell specificity. Several different cell types may bind one specific monoclonal antibody by sharing a common antigen or else by possessing "look-alike" antigens. Quite frequently, cells that share a common antigen also share a common embryological derivation. Monoclonal antibodies should therefore be considered to show antigen specificity rather than cell specificity. By using combinations of characterised antibodies to form a diagnostic panel, a cell type can be accurately identified by its own unique antigenic profile. The antibodies chosen for inclusion in the diagnostic CSF panel reflect the common tumour types that invade the CSF and have been reliably characterised by testing on a wide variety of tissues. 
Neoplasia of the CSF falls into four major tumourantigen categories: carcinoma, neuroectodermal tumour, melanoma and lymphoma. The panel should consist of antibody markers for each of these major tumour categories, but additional antibodies may be added for more detailed cellular characterisations or in cases where a specific tumour type is suspected. In this series of melanoma patients, up to four different melanoma antibody markers have been used in the diagnostic panel in addition to the antibody markers for other tumour categories. Some of the antibody markers cross react with other tumours of neuroectodermal origin (table 2). The value of the well characterised antibody UJ13A is shown in this situation as it is known to bind a glycoprotein antigen present on all cells and tumours derived from neuroectoderm, with the one strict exception of melanoma. ${ }^{12}$ Therefore, in the presence of positive binding by antibodies which recognise melanoma, a negative response to UJ13A is absolute confirmation of melanoma. This example therefore emphasises the point that for accurate cellular identification, it is the pattern of reactivity to the entire panel of antibodies that is diagnostic rather than reactions with single antibodies. The distinctive antigenic profile of any specific tumour is contributed as much from negative markers as from positive.

In conclusion, neoplastic meningitis is a common complication of advanced neoplastic disease, for which treatment by radioimmunotherapy may be an effective option. We therefore recommend an active search for evidence of leptomeningeal spread in patients with advanced malignant disease who develop neurological symptoms or signs. This is now facilitated by the application of monoclonal antibody technology to diagnostic CSF cytology.

This work was generously supported by grants from the following organisations; The Preuss Foundation Inc.; The Sir Jules Thorn Charitable Trust; The Francis and Augustus Newman Foundation; The Skin Cancer Research Fund; The Bristol Brain Tumour Research Fund; and the Imperial Cancer Research Fund. We also thank Dr E Birgitte Lane, Dr Clive Woodhouse and Dr J T Kemshead for donating antibodies for this study. Dr P M Norman kindly provided cytology data on case 1 . We thank Miss Alison Hinchley for her untiring efforts in typing the manuscript.

\section{References}

1 Olsen M, Chernik N, Posner J. Infiltration of the leptomeninges by systemic cancer. A clinical and pathological study. Arch Neurol 1974;30:122-37.

2 Aroney RS, Dalley DN, Chan WK, Bell DR, Levi JA. Meningeal carcinomatosis in small cell carcinoma of the lung. Am J Med 1981;71:26-32.
3 Yap H-Y, Yap B-S, Tashima CK, Distenfano A, Blumenschein GR. Meningeal carcinomatosis in breast cancer. Cancer 1978;42:283-6.

4 Little JR, Dale AJD, Okazaki H. Meningeal carcinomatosis. Clinical manifestations. Arch Neurol 1974;30:138-43.

5 Amer MH, Al-Sarraf M, Baker LH, Vaitkevicius UK. Malignant melanoma and central nervous system metastases. Incidence, diagnosis, treatment and survival. Cancer 1978;42:660-8.

6 Bigner SH, Johnston WW. Cytopathology of cerebrospinal fluid. Acta Cytol 1981;25:461-79.

7 Coakham HB, Garson JA, Brownell DB, et al. Use of monoclonal antibody panel to identify malignant cells in cerebrospinal fluid. Lancet 1984;ii:1095-8.

8 Morgan AC, Galloway DR, Reisfeld RA. Production and characterisation of monoclonal antibody to a melanoma specific glycoprotein. Hybridoma 1981;1:27-36.

9 Vennegoor J, Calafat J, Hageman Ph, et al. Biochemical Characterization and Cellular localisation of a Formalin-Resistant Melanoma-Associated antigen reacting with monoclonal antibody NK1/C3. Int J Cancer 1985;35:287-95.

10 Carrel S, Accolla RS, Carmagnoa AL, Mach J-P. Common Human Melanoma-Associated Antigen(s) detected by monoclonal antibodies. Cancer Res 1980;40:2523-8.

11 Nakajima T, Watanabe S, Sato Y, Kameya T, Shimosato Y, Ishihara $\mathrm{K}$. Immunohistochemical Demonstration of S-100 Protein in Malignant Melanoma and pigmented nevus, and its diagnostic application. Cancer 1982;50:912-8.

12 Allan P, Garson J, Harper E, et al. Biological Characterization and Clinical Applications of a monoclonal antibody recognising an antigen restricted to Neuroectodermal tissues. Int J Cancer 1983;31:591-8.

13 Lane EB. Monoclonal Antibodies provide specific intramolecular markers for the study of epithelial tonofilament organisation. J Cell Biol 1982;92:665-73.

14 Garson J. MD Thesis Birmingham University, 1983.

15 Pizzolo G, Sloane J, Beverley P, et al. Differential Diagnosis of Malignant Lymphoma and Non-Lymphoid tumours using monoclonal Anti-Leucocyte Antibody. Cancer 1980;46:2640-7

16 Garson JA, Coakham HB, Kemshead JT, et al. The role of monoclonal antibodies in brain tumour diagnosis and cerebrospinal fluid cytology. J Neurooncol 1985;3:165-71.

17 Mackie RM, Campbell I, Turbitt ML. Use of NK1/C-3 Monoclonal Antibody in the assessment of benign and malignant melanocytic lesions. J Clin Pathol 1984;37:367-72.

18 Leader M, Collins M, Patel J, Henry K. Vimentin: An evaluation of its role as a tumour marker. Histopathology 1987;11:63-72.

19 Schiffer D, Giordana MT, Mauro A, Migheli A, Germano I, Giaccone G. Immunohistochemical demonstration of vimentin in human cerebral tumours. Acta Neuropathol (Berl) 1986; 70:209-19.

20 Chason JL, Walker FB, Landers JW. Metastatic carcinoma in the central nervous system and dorsal root ganglia. A prospective autopsy study. Cancer 1963;16:781-7.

21 Patel JK, Didolkar MS, Pickren JW, Moore RH. Metastatic pattern of malignant melanoma. A study of 216 autopsy cases. Am J Surg 1978;135:807-10.

22 Coakham HB, Davies AG, Richardson RB, et al. Antibodyguided irradiation therapy for neoplastic meningitis. In: Chatel M, Darcel F, Pecker J, eds. Brain Oncology. Dordrecht: Martinus Nijoff, 1987:349-52.

23 Lashford LS, Davies AG, Richardson RB, et al. A Pilot Study of 131-I Monoclonal Antibodies in the Therapy of Leptomeningeal Tumours. Cancer 1988;61:657-86.

24 Coakham HB, Richardson RB, Davies AG, Bourne SP, Eckhert $H$, Kemshead JT. Neoplastic Meningitis from a Pineal Tumour Treated by Antibody-guided Irradiation via the Intrathecal Route. Br J Neurosurg 1988;2:199-209.

25 Coakham HB, Kemshead JT. The present role of monoclonal antibodies in the diagnosis and therapy of brain tumours. Wiener klinische Wochenscrift 1987;99:372-8.

26 Vick WW, Bigner SH, Wikstrand CJ, et al. The use of a panel of monoclonal antibodies in the evaluation of cytologic specimens from the central nervous system. Acta Cytol 1987;31:815-24. 